\title{
PSYCHE.
}

\section{DIPTERA OF THE ORGAN MOUNTAINS IN SOUTHERN NEW MEXICO. - II.}

BY C. H. TYLER TOWNSEND, LAS CRUCES, NEW MEXICO.

In the latter part of August, 1897, a few days were spent collecting in Filmore Cañon, and on the main ridge of the Organs above its head. The more notable results of this collecting are here given. Filmore Cañon runs down the west slope of the range, and is about five miles long, its head being about 8,000 feet and its mouth about 5, 000 feet altitude above sea. During the moister season of the year a stream of clear cold water courses down the cañon, flowing over sandy beds and amongst boulders, often dropping from a few to ten or fifteen feet over masses of rock, finally dashing down a wall about fifty feet in height some distance within the mouth of the cañon. At the time of the above visit the bed of the stream was for the most part dry in the upper three or four miles of its course, the water seeping out at intervals but soon disappearing again.

5. Tersesthes torrens Towns. Thirteen females taken on horses, at camp in Filmore Cañon, about 6,000 ft., August 29, 1897. They were particu- larly bad about the horses' heads, especially about the eyes.

This species was discovered by me June $2 \mathrm{I}, \mathbf{1 8 9 2}$, on the Continental Divide, 7,000 ft., six miles west of Patterson, in Socorro county, N. M. The genus and species were described in Psyche, January, r893 (vol. 6, pp. 369-37 I, with pl. 8). The present specimens found in Filmore Cañon, Organ Mts., are the first and only ones that have come to notice since the discovery of the original specimens. The genus and species are easily recognizable by the descriptions and plate in Psyche.

6. Volucella victoria Will. Three males, top of ridge above head of Filmore Cañon, about 8,500 ft., August 28, two being taken on flowers of a grass, Bouteloua sp., prob: hirsuta Lag. (det. Tinsley), and the other on flowers of Chrysopsis villosa Nutt. var. (det. Tinsley).

7. Copestylum marginatum Say, var. One male, top of ridge above head of Filmore Cañon, about 8,500 ft., Au- 
gust 28, on flowers of Eriogonum jamesii Benth. (det. Tinsley).

Length, $1 \circ \frac{1}{2} \mathrm{~mm}$. (not incl. antennae). Yellow stripe of cheeks not reaching oral margin. Antennae light yellowish red, except black arista. Yellow spots of frontal triangle subobsolete, pile black. Pile of thoracic dorsum black, of pleura whitish, no yellow on sides of dorsum nor in front of scutellum. Fourth abdominal segment with no trace of a band, wholly greenish black, clothed with white pile. The reddish yellow bands of second and third segments are well separated. Second and third segments of venter yellowish. Proximal half of tibiae yellowish, metatarsi more or less reddish.

This specimen can not be referred to Williston's var. lentum, but may be intermediate between lentum and the normal form.

8. Cuterebra nitida Coq. Two males, Filmore Cañon, about 6,000 ft., August 27,1897 . These specimens, and others which were seen but not captured, were found flying up and down the bed of the stream at the camp, and alighting on rocks beside or between the pools of running water.

They agree with Coquillett's description, except that the two opaque pollinose spots contiguous to the eyes are not distinct, and the abdomen shows faint suggestions of pollen in certain lights at extreme base.

9. Peleteria iterans Walk. Two females. One on flowers of Chrysopsis villosa Nutt. var., top of ridge above head of Filmore Cañon, about $8,500 \mathrm{ft}$., August 28. The other, Filmore Cañon, about 6,000 ft., August 27 .

This is the species which I have always identified as Echinomyia (Peleteria) iterans Walk. According to $\mathrm{Mr}$. D. W. Coquillett's Revision of Tachinidae of America north of Mexico (Techn. Bull. No. 7 Div. Ent. U. S. Dept. Agric.), this species would be known as Peleteria tessellata Fab. From a lack of evidence upholding the synonyms given in this work, I am constrained to continue to call. this species $P$. iterans. There are many reasons which make the synonymy given by Mr. Coquillett under Peleteria and Archytas extremely doubtful. I have followed Williston's conception of P. iterans Walk. (Trans. Am. Ent. Soc. XIII, p. 30I), in considering that it possessed the bristles contiguous to lower portion of eyes; while in the above "Revision" iterans Walk. is placed in Archytas in which these bristles are absent, and is moreover made a synonym of $A$. lateralis Mcq. (formerly known as Jurinia lateralis)! Further, we have only the author's dictum that the present species is the same as the European tessellata Fab.; while both Brauer and Bergenstamm and van der Wulp, who ought to know the European form, have considered the American different. This is only one of the many examples of incongruity, and lack of substantiating evidence for statements made, to be found in $\mathrm{Mr}$. Coquillett's paper, to which I shall have occasion to refer in detail at another time. 
ro. Peleteria thomsoni Will. Twenty specimens ( 88 and $2 \%$ ), varying from small to large, as follows: Sixteen males, top of ridge above head of Filmore Cañon, about 8,500 ft., August 28, six taken on flowers of Eriogonum jamesii Benth. One male and one female, Filmore Cañon, about $6000 \mathrm{ft}$., August 29, on flowers of Gutierrezia sarothrae. One male and one female in cop., Filmore Cañon, about $7000 \mathrm{ft}$., August 28, on flowers of Gutierrezia sarothrae.

I I. Gaediopsis monticola n. sp. One male, top of ridge above head of Filmore Cañon, about 8,500 ft., August 28.

Length, $1 \circ \frac{1}{2} \mathrm{~mm}$. Differs from description of $G$. setosa Coq. (Rev. Tach. p. 136) as follows: Tibiae yellowish red, the anterior ones blackish at base. Face and sides of front pale yellowish, former silvery and latter cinereous pollinose. Second antennal joint yellowish or reddish. Sides of abdomen on first, second, and third segments broadly pale red, leaving a broader median area of black between, which widens posteriorly. Front at bases of antennae twice as wide as either eye, at vertex one and one-fifth times width of either eye. The fine bristly hairs on sides of face are in two parallel approximated rows near margin of eyes, there being none between the lateral facial row and the facial ridge row. Cheeks ąs broad as one-half eyeheight, clothed with bristly hairs. Antennae four-fifths as long as face, third joint nearly or quite three times as long as second. First aristal joint as long as wide; second four or five times as long as first, and fully one-third total length of last joint, which is much tapered on its final third. The middle tibiae each bear four macrochaetae on front side, the fourth or upper one the shortest, increasing in length to the lowest one which is longest. Otherwise agrees in all respects with the characters given for G. setosa.

\section{NOTES ON NEW ENGLAND ACRIDIIDAE, IV, - ACRIDIINAE, III.}

BY ALBERT P. MORSE, WELLESLEY, MASS.

\section{Schistocerca Stål.}

Schistocerca Stål 1873. Recensio orthopterorum, I, 73.

This genus includes locusts of large size and rapid and powerful flight; they are somewhat arboreal in habit, frequently alighting or feeding on trees and shrubs.
31. Schistocerca rubiginosa Harris. Fig. 3 .

Acridium rubiginosum. Harris Mss. in Scudder, Materials etc., BQston Journ. Nat. Hist., VII, 467 (1862); Thomas, Syn. Acrid., I 70 ; Fernald, Orth. N. E., 3 I ; Comstock, Introd., I 6 ; Beutenmüller, Orth. N. Y., 304. 

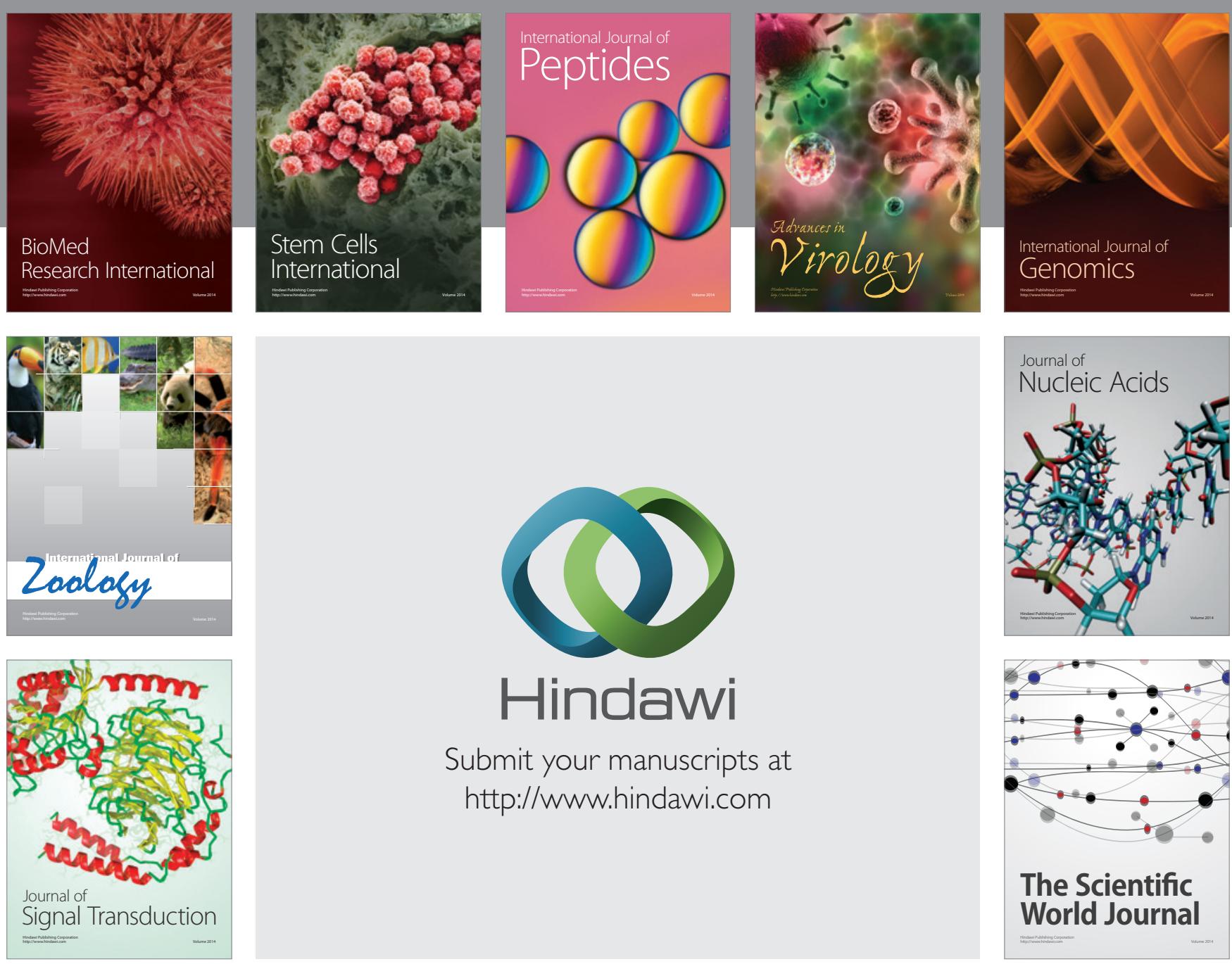

Submit your manuscripts at

http://www.hindawi.com
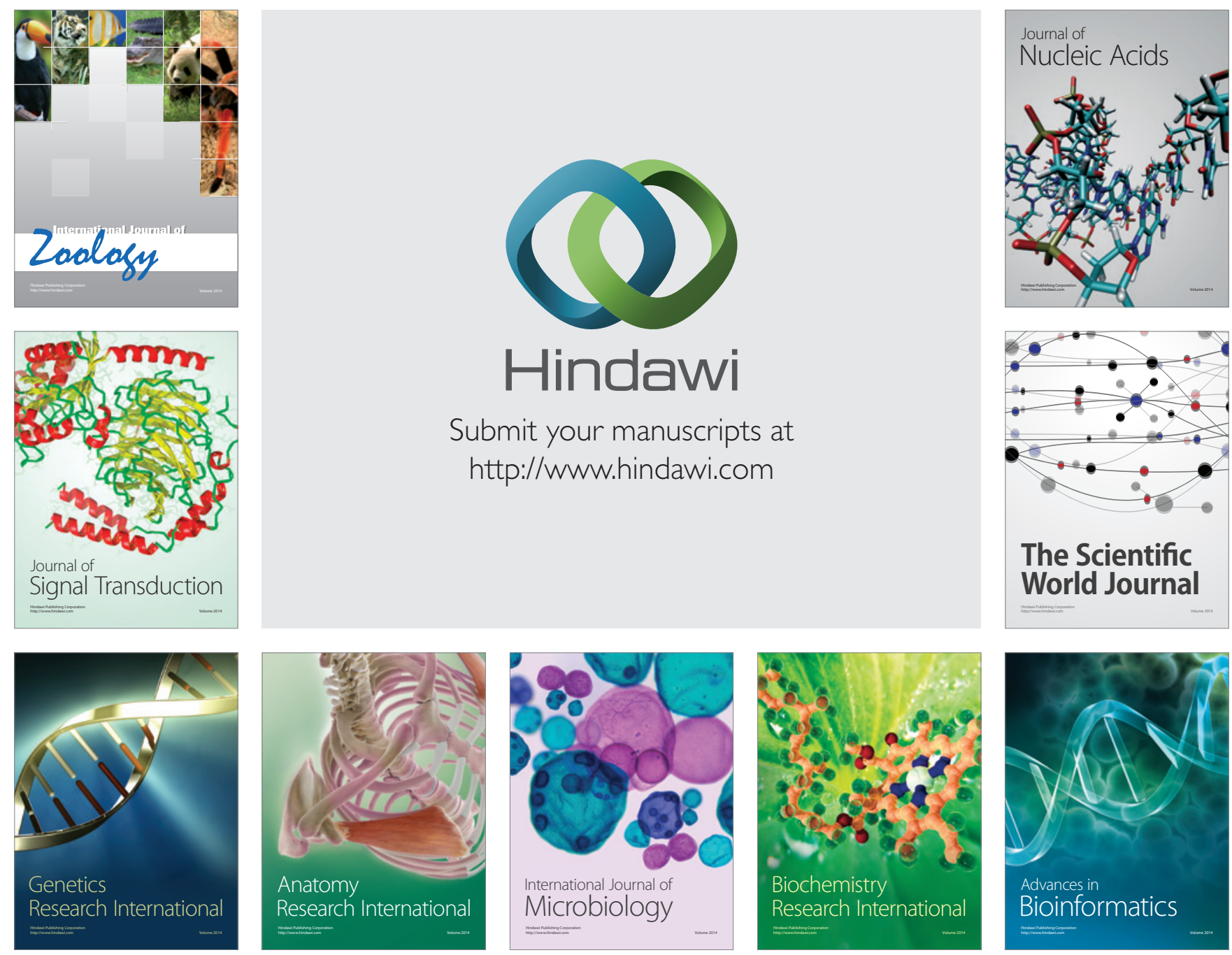

The Scientific World Journal
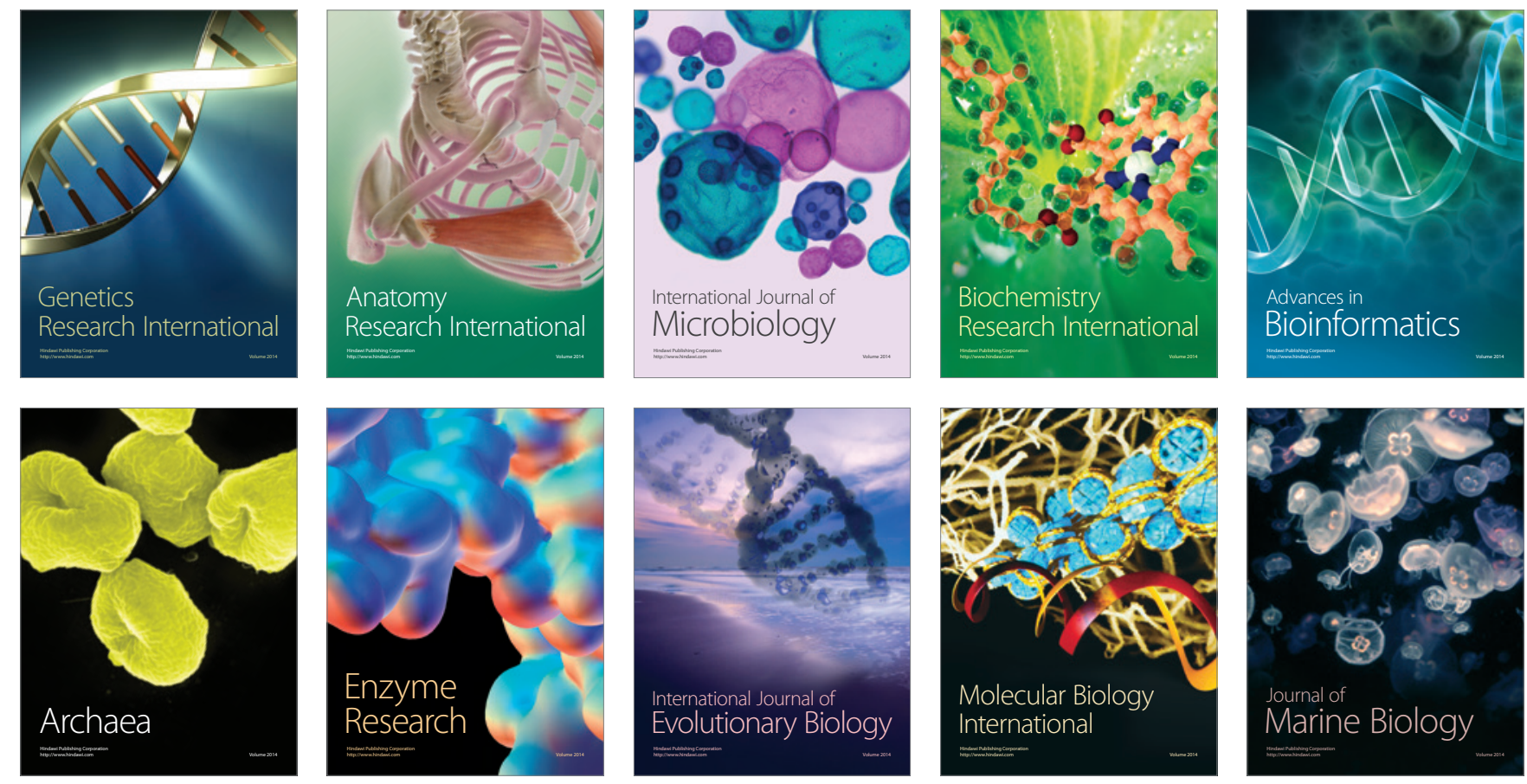